Mr Slavko Muždeka, kapetan I klase, dipl. inž. Vojna akademija - Odsek logistike, Beograd

\section{STRUKTURNA ANALIZA SLOŽENIH PLANETARNIH PRENOSNIKA SNAGE}

UDC: $621.833 .6: 531.1$

Rezime:

Određivanje osnovnih kinematičkih i dinamičkih karakteristika složenih planetarnih prenosnika je složen proces za koji je razvijeno više analitičkih, grafičkih i grafoanalitičkih metoda. U radu je prikazan način odredivanja prenosnog odnosa, opterećenja elemenata i tokova snage za planetarni red sa spoljašnjim i unutrašnjim ozubljenjem preko polužne analogije i primene strukturnog (Wolfovog) simbola. Polužna analogija definisana je i za planetarni red sa spoljašnjim ozubljenjem, za koji je, takođe, definisan strukturni simbol. Definisani strukturni simboli iskorišćeni su za definisanje strukture prenosnika tipa Ravigneaux. Primena strukturne šeme za analizu karakteristika složenih planetarnih prenosnika ilustrovana je kroz analizu određenih funkcionalnih stanja planetarnih menjačkih prenosnika. Posebno je definisana mogućnost analize blokiranih stanja planetarnih menjačkih prenosnika.

Ključne reči: planetarni prenosnici, prenosnik Ravigneaux, polužna analogija, strukturna šema, analiza stanja.

\title{
STRUCTURAL ANALYSIS OF COMPOUND PLANETARY GEAR TRAINS
}

Summary:

Determination of basic kinematic and dynamic characteristics of compound planetary gear trains is complex process. Therefore there are many analytical, graphical and graphicanalytical methods. This paper presents method of determination gear ratios, loads and power flows for planetary gear set with the sun and ring gear by lever analogy with the application of Wolf's structural symbol. The lever analogy and structural symbols are also defined for the planetary gear set with two sun gears. Defined structural symbols are employed for definition of Ravigneaux gear structure. Application of structural schemes for an analysis of compound planetary gear trains is illustrated through analysis of certain planetary gearboxes functional state. The possibility of analysis of blocked compound planetary gear train is defined too.

Key words: planetary gear trains, Ravigneaux gear train, lever analogy, structural scheme, analysis.

\section{Uvod}

U oblasti zupčastih prenosnika snage planetarni prenosnici imaju sve širu primenu u odnosu na prenosnike sa nepokretnim osama zbog brojnih prednosti
- manjeg opterećenja, manjih dimenzija, saosnosti ulaznog i izlaznog vratila, većeg stepena korisnosti i sl. Planetarni prenosnici koji se najčešće primenjuju su jednoredni sa spoljašnjim i unutrašnjim ozubljenjem i složeni - višeredni preno- 
snici. Posebnu grupu složenih planetarnih prenosnika čine prenosnici tipa Ravigneaux $[1,2,3]$ koji se često primenjuju u menjačkim prenosnicima motornih vozila. Kinematička i dinamička analiza planetarnih prenosnika znatno je složenija nego analiza prenosnika sa nepokretnim osama. Za određivanje prenosnog odnosa, opterećenja elemenata i određivanje tokova snage kod planetarnih prenosnika razvijeno je više analitičkih, grafoanalitičkih i grafičkih metoda koje su, $\mathrm{u}$ većoj ili manjoj meri, kompleksne i zahtevaju relativno složen matematički aparat. U radu je prezentovana kinematička i dinamička analiza određenih funkcionalnih stanja karakterističnih predstavnika planetarnih menjačkih prenosnika pomoću metode strukturne analize uz primenu polužne analogije koja je razrađena $\mathrm{u}$ radovima $[4,5,6] \mathrm{i}$ upotrebu Wolfovog strukturnog simbola $[7,8,9]$. Pored primene polužne analogije za planetarni red sa spoljašnjim i unutrašnjim ozubljenjem razrađena je primena navedene analogije za planetarni red sa spoljašnjim ozubljenjem i prenosnik tipa Ravigneaux.

\section{Strukturni modeli osnovnih planetarnih prenosnika}

Na slici 1a) prikazan je model planetarnog reda sa spoljašnjim i unutrašnjim ozubljenjem koji je najšire primenjen kao samostalni planetarni prenosnik ili element složenog prenosnika. U opštem slučaju to je četvoročlani zupčasti mehanizam sa dva stepena slobode od kojih se tri člana (centralni zupčanici i nosač satelita) mogu koristiti za vezu sa elementima koji prenose snagu. Prenosnik će biti u ravnoteži ukoliko je suma spoljašnjih momenata na njegovim elementima jednaka nuli, $\mathrm{tj}$.:

$\Sigma T=T_{a}+T_{b}+T_{H}=0$

Odnos momenata na elementima planetarnog prenosnika je:

$T_{a}: T_{b}: T_{H}=+1:+k:-(1+k)$

Parametar $\mathrm{k}$ je unutrašnji prenosni odnos koji je jednak odnosu momenata na centralnom zupčaniku sa unutrašnjim ozubljenjem i centralnom zupčaniku sa spoljašnjim ozubljenjem, odnosno, odnosu broja zubaca navedenih zupčanika:

$k=\frac{T_{b}}{T_{a}}=\frac{z_{b}}{z_{a}}$

Unutrašnji prenosni odnos kod navedene realizacije planetarnog prenosnika uvek je veći od jedinice, a u praktičnim realizacijama prenosnika najčešće je u dijapazonu od 1,5 do 4,5 [1]. Odnos momenata na elementima prenosnika uvek odgovara izrazu (1), bez obzira na to da li je prenosnik u funkciji delitelja snage - diferencijala, sabirača snage ili prenosnika sa jednim stepenom slobode. Kod složenih prenosnika svaki planetarni red može se posmatrati posebno, tako što se uticaj elemenata susednih planetarnih redova koji su vezani sa posmatranim redom zamenjuje momentom koji je po veličini jednak momentu na elementu susednog reda, samo sa promenjenim predznakom. 


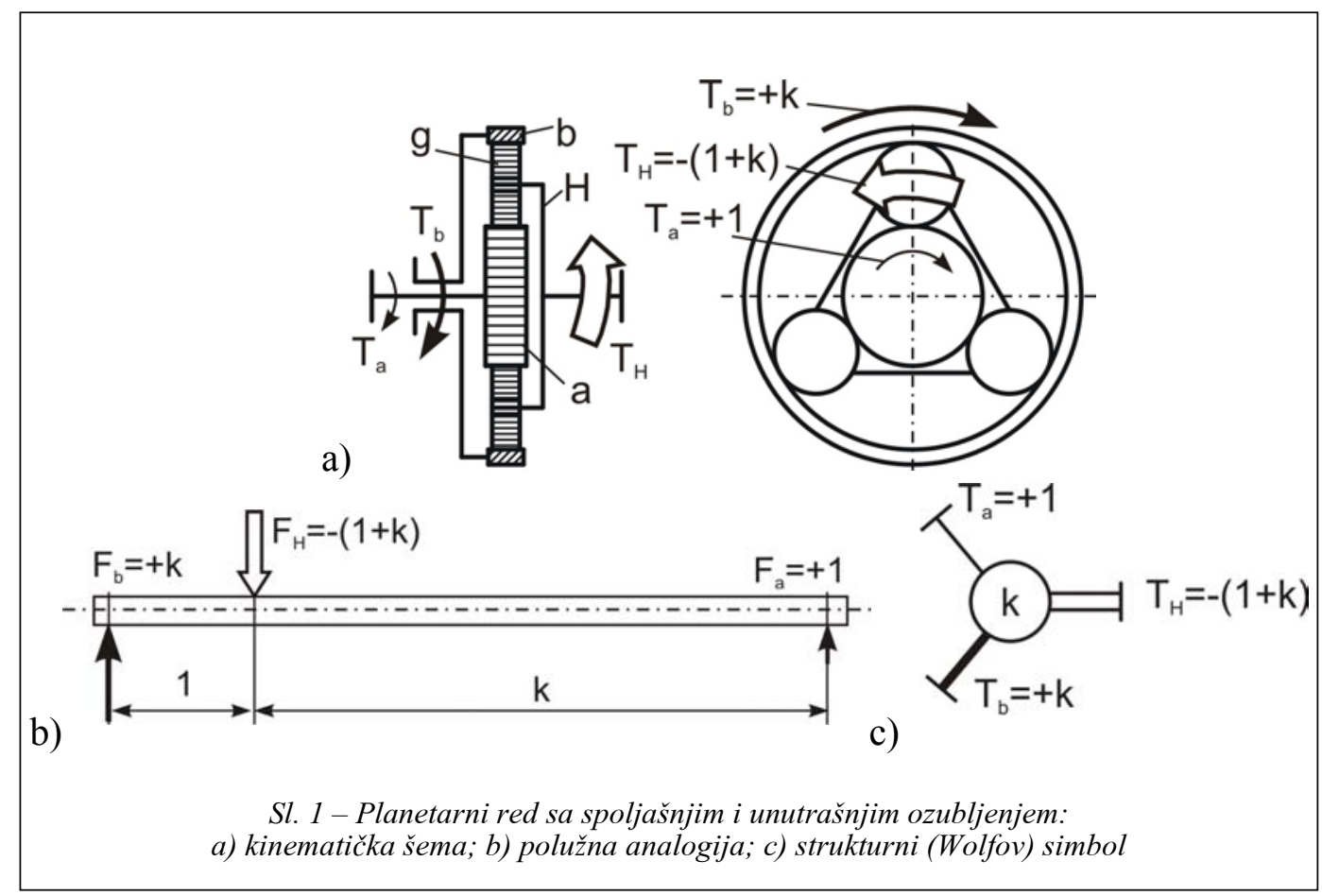

Analogno opterećenjima planetarnog reda, ukoliko se problem posmatra u linearnom koordinatnom sistemu, dobija se odnos sila koje deluju na polugu koja je u ravnoteži, kako je prikazano na slici 1b). Analogija je očigledna i potpuna i po smeru i intenzitetu opterećenja. Da bi se izbeglo označavanje članova, a radi povećavanja jasnoće i olakšavanja izračunavanja, uveden je strukturni - Wolfov simbol [7, 8, 9], slika 1c), koji omogućava lako određivanje opterećenja elemenata prenosnika. Simbol se sastoji od kruga u kojem je upisan unutrašnji prenosni odnos planetarnog reda i tri linije koje simbolizuju članove koji mogu da se iskoriste kao pogonski, gonjeni i kočeni (centralni zupčanici i nosač satelita). Tankom linijom označen je član sa najmanjim momentom, što odgovara momentu na centralnom zupčaniku sa spo- ljašnjim ozubljenjem. Debelom linijom označen je moment na centralnom zupčaniku sa unutrašnjim ozubljenjem koji je jednak proizvodu momenta na centralnom zupčaniku i unutrašnjeg prenosnog odnosa. Sumarni moment, koji uravnotežava prethodna dva, deluje na elementu koji je označen duplom linijom, a to je nosač satelita. Na taj način nedvosmisleno su i jednoznačno određeni momenti na elementima planetarnog reda, bilo da se radi o jednostavnom ili o složenom prenosniku. Ukoliko se jedan element planetarnog reda zakoči, on postaje prenosnik sa jednim stepenom slobode i prenosnim odnosom jednakim odnosu ugaonih brzina ulaznog i izlaznog člana. Kod složenih prenosnika sa jednim stepenom slobode prenosni odnos se, takođe, određuje kao odnos ugaonih brzina ulaznog $\mathrm{i}$ izlaznog člana, tj.: 
$i=\frac{\omega_{u l}}{\omega_{i z l}}$

Pod pretpostavkom da se zanemaruju gubici snage unutar prenosnika i da se zanemare inercijalne sile (slučaj ravnomernog obrtanja elemenata prenosnika), u skladu sa zakonom o održanju energije, važe sledeći izrazi

$$
\begin{aligned}
& P_{u l}+P_{i z}=0 \\
& T_{u l} \omega_{u l}+T_{i z} \omega_{i z}=0 \\
& i=\frac{\omega_{u l}}{\omega_{i z}}=-\frac{T_{i z}}{T_{u l}}
\end{aligned}
$$

Izraz (7) pokazuje da se prenosni odnos može odrediti na osnovu odnosa momenata na izlaznom i na ulaznom elementu, što se može iskoristiti u situaciji kada je lakše odrediti obrtne momente nego ugaone brzine.

$\mathrm{Na}$ slici 2a) prikazana je kinematička šema planetarnog prenosnika sa spoljašnjim ozubljenjem koji se ređe koristi u praksi. Ovaj prenosnik ima tri člana, preko kojih se ostvaruje veza sa drugim elementima i može da ostvari istovetna kinematička stanja kao planetarni red sa spoljašnjim i unutrašnjim ozubljenjem. Označavanje elemenata prenosnika je analogno kao kod planetarnog reda sa

a)
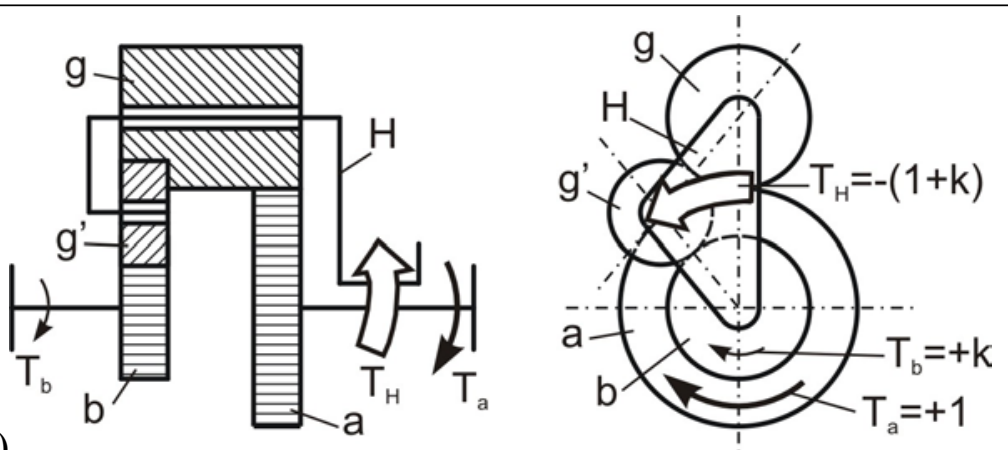

b)
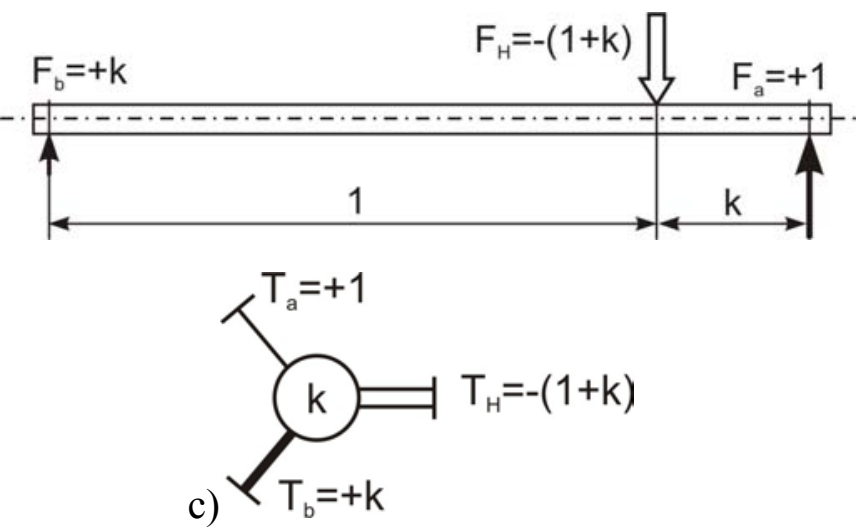

Sl. 2 - Planetarni red sa spoljašnjim ozubljenjem: a) kinematička šema; b) polužna analogija; c) strukturni simbol 


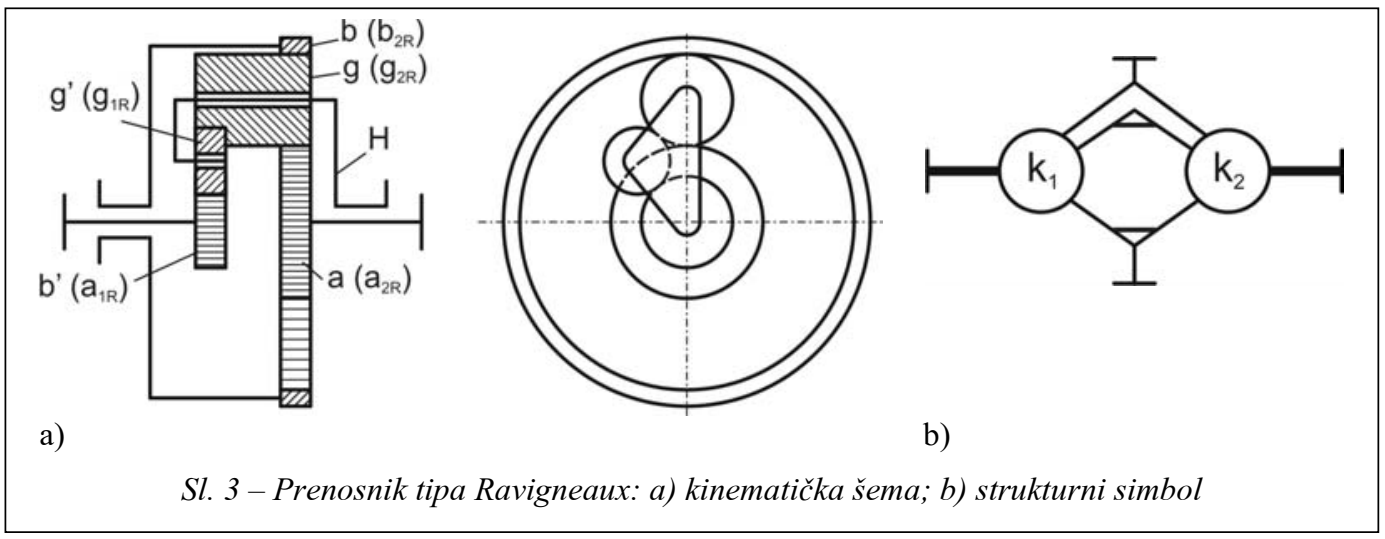

spoljašnjim i unutrašnjim ozubljenjem. Zbog činjenice da su oba centralna zupčanika sa spoljašnjim ozubljenjem, na nosaču satelita postoje dva satelita koji su međusobno uzubljeni, tako da se smerovi ugaonih brzina i opterećenja članova poklapaju sa smerovima ekvivalentnih veličina planetarnog reda sa spoljašnjim i unutrašnjim ozubljenjem. Unutrašnji prenosni odnos, za razliku od planetarnog reda sa spoljašnjim i unutrašnjim ozubljenjem, može biti manji, jednak ili veći od jedinice, što stvara razliku između ova dva planetarna reda. Jednačine (1), (2) i (3) važe i za ovaj prenosnik, ali veličine momenata na zupčanicima a i b mogu biti različite $u$ odnosu na planetarni red sa spoljašnjim i unutrašnjim ozubljenjem. $\mathrm{Na}$ slici 2a) prikazana je realizacija planetarnog reda sa spoljašnjim ozubljenjem i unutrašnjim prenosnim odnosom manjim od jedinice sa pripadajućim momentima, a na slici $2 b$ ) prikazana je polužna analogija za ovaj prenosnik. Vidi se da je moment na centralnom zupčaniku b manji od momenta na zupčaniku a i da je krak k manji od jedinice. Ukoliko se želi zadržati analogija sa prenosnikom na slici 1, ovakvo stanje opterećenja ne mora da ima uticaj, pa označavanje ovog pre- nosnika pomoću strukturnog simbola može ostati istovetno, slika 2c). Povećavanjem dimenzija zupčanika $b$, a smanjivanjem zupčanika a dobija se povećanje unutrašnjeg prenosnog odnosa $\mathrm{k}$ koji može i preći jedinicu, kada se dobija situacija potpuno analogna prenosniku na slici 1.

Planetarni prenosnik tipa Ravigneaux može se predstaviti kao složeni prenosnik kod kojeg su vezani jedan planetarni red sa spoljašnjim i unutrašnjim ozubljenjem i planetarni red sa spoljašnjim ozubljenjem, kako je to prikazano na slici 3. Prvi planetarni red je sa spoljašnjim ozubljenjem i čine ga centralni zupčanici a i b', sateliti g i g' i nosač satelita H. Unutrašnji prenosni odnos $\mathrm{k}_{1}$ jednak je odnosu broja zubaca zupčanika b' i zupčanika a i kod praktičnih realizacija prenosnika nalazi se u dijapazonu od 0,5 do 0,8 (izuzetno 0,92$)[1]$. Teorijski postoji mogućnost da prenosni odnos $\mathrm{k}_{1}$ bude veći $\mathrm{i}$ da se kreće u dijapazonu od 0,5 do 1,5 [10]. Drugi planetarni red čine centralni zupčanici a i b, satelit g i nosač satelita $\mathrm{H}$. Unutrašnji prenosni odnos $k_{2}$ jednak je odnosu broja zubaca zupčanika b i zupčanika a i nalazi se u dijapazonu od 1,5 do 4,5.

Da bi se obezbedila analogija sa označavanjem elemenata unutar složenih 
planetarnih prenosnika koji se sastoje od planetarnih redova sa spoljašnjim i unutrašnjim ozubljenjem, u literaturi [1] se elementi prenosnika tipa Ravigneaux označavaju na način kako je to prikazano na šemi, slika 3a), u zagradama. Na taj način se kod složenog prenosnika koji se sastoji od planetarnih redova sa spoljašnjim i unutrašnjim ozubljenjem elementi označavaju slovima (kao na slici 1) sa indeksima koji označavaju mesto planetarnog reda. Prvi planetarni red je onaj koji je najbliži ulaznom vratilu, a poslednji onaj koji je najbliži izlaznom vratilu. Kod prenosnika tipa Ravigneaux centralni zupčanici sa spoljašnjim ozubljenjem označavaju se slovom, a sa pripadajućim indeksom koji pored broja ima i slovo R. Manji broj je uvek vezan za centralni zupčanik sa spoljašnjim ozubljenjem koji nije unutar planetarnog reda sa spoljašnjim i unutrašnjim ozubljenjem. U navedenoj literaturi prenosnik sa elementima $a_{1 R}, g_{1 R}, i H$ naziva se nepotpuni planetarni red.

Ukoliko se prenosnik tipa Ravigneaux posmatra kao složeni prenosnik koji se sastoji od dva planetarna reda sa zajedničkim centralnim zupčanikom, a i nosačem satelita $\mathrm{H}$ za oba planetarna reda, može se predstaviti kao dvoredni prenosnik sa čvrsto vezanim nosačima sate- lita i centralnim zupčanicima, kako je prikazano na strukturnoj šemi, slika 3b). Centralni zupčanici i nosač satelita su na strukturnoj šemi vezani dodatnom linijom, što simbolizuje da su izrađeni izjedna. Prenosnik tipa Ravigneaux ima dva stepena slobode, iako ima četiri člana koji se mogu koristiti za vezu sa elementima izvan prenosnika. Opterećenje elemenata $i$ tok snage kroz prenosnik u velikoj meri zavise od toga koji element je pogonski, kočeni, gonjeni ili slobodan. Ukoliko je slobodan jedan od zajedničkih članova (nosač satelita $\mathrm{H}$ ili centralni zupčanik a) oba planetarna reda prenose snagu, a ako je jedan od centralnih zupčanika b ili b' slobodan, tada planetarni red čiji element je slobodan ne prenosi snagu.

\section{Odredivanje prenosnog odnosa, opterećenja i tokova snage}

Da bi se prikazala mogućnost primene strukturnog simbola za analizu kinematičkih i dinamičkih karakteristika prenosnika, razmatraće se dvoredni prenosnik čija je kinematička šema prikazana na slici 4.

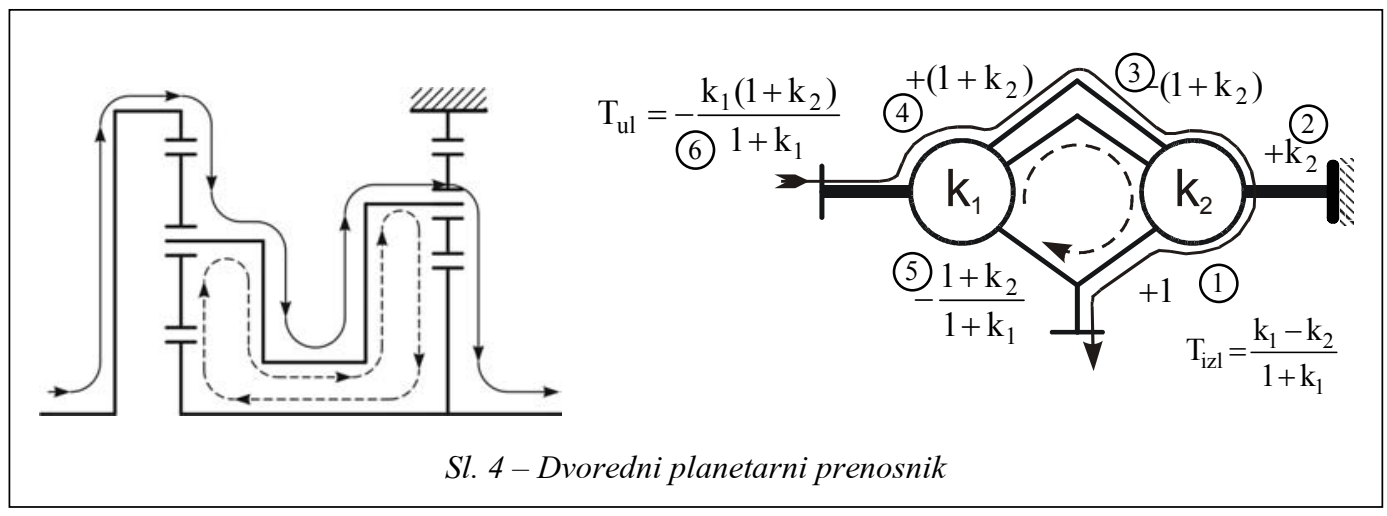




\section{Odredivanje opterećenja elemenata prenosnika}

Da bi se odredili obrtni momenti koji deluju na elemente prenosnika, posmatra se posebno svaki planetarni red unutar prenosnika. Za prenosnik na slici 4 redosled određivanja opterećenja prikazan je brojevima u krugovima na strukturnoj šemi. Na centralnom zupčaniku prvog posmatranog planetarnog reda $(\mathrm{u}$ slučaju na slici 4 to je planetarni red 2) pretpostavi se vrednost momenta jednaka +1 . Moment na ostalim elementima posmatranog prenosnika jednostavno se određuje na osnovu izraza (2). Kada su određeni momenti na prvom posmatranom planetarnom redu prelazi se na drugi, $\mathrm{s}$ tim što se veza sa elementom koji je direktno vezan sa elementom prethodnog planetarnog reda zamenjuje momentom na tom elementu, ali sa suprotnim predznakom. To je slučaj sa vezom nosača satelita, gde je moment na nosaču prvog planetarnog reda jednak momentu na nosaču drugog sa negativnim predznakom. Ukoliko je više elemenata vezano, potrebno je zadovoljiti uslov da u čvornoj tački suma momenata bude jednaka nuli. Moment na ostalim elementima prvog planetarnog reda izračunava se na osnovu izraza (2). Moment na ulaznom i izlaznom elementu prenosnika jednak je sumi momenata članova vezanih za ulazni, odnosno izlazni element.

Kod složenih višerednih prenosnika potrebno je voditi računa o tome koji planetarni red se prvi razmatra, jer od izbora prvog planetarnog reda zavisi složenost izračunavanja momenata. Da bi se opterećenja svih elemenata izrazila u funkciji ulaznog momenta potrebno je svaki izra- čunati moment pomnožiti sa recipročnom vrednošću momenta na ulazu. Na taj način ulazni moment postaje jednak jedinici.

Moment na blokiranom elementu ili elementima jeste spoljašnji moment $[6$, 9] i može služiti za kontrolu izračunavanja opterećenja, pošto mora biti zadovoljena jednačina:

$T_{u l}+T_{i z}+T_{k}=0$

gde je:

$T_{u l}$ - ulazni moment,

$T_{i z}$ - izlazni moment,

$T_{k}$ - ukupan moment na svim blokiranim elementima.

U konkretnom slučaju jednačina (8) je zadovoljena, što znači da su opterećenja elemenata adekvatno određena.

\section{Odredivanje prenosnog odnosa}

Prenosni odnos prenosnika određuje se na osnovu izraza (4) i za prenosnik prikazan na slici 4 iznosi:

$i=\frac{k_{1}-k_{2}}{k_{1}\left(1+k_{2}\right)}$

Izraz za prenosni odnos pokazuje da u konkretnom slučaju smer obrtanja izlaznog elementa prenosnika zavisi od odnosa unutrašnjih prenosnih odnosa $k_{1} \mathrm{i} k_{2}$. Ukoliko je $k_{1}>k_{2}$ prenosni odnos prenosnika je pozitivan i nema promene smera obrtanja, dok u suprotnom dolazi do promene smera obrtanja.

\section{Odredivanje tokova snage}

Snaga unutar složenog planetarnog prenosnika, u opštem slučaju, prenosi se preko više tokova, uz mogućnost da se u 
zatvorenoj konturi pojavi i cirkulirajuća snaga. Uslov za pojavu cirkulirajuće snage jeste da unutar prenosnika postoji zatvorena kontura i cirkulirajući moment koji pri radu prenosnika izaziva cirkulaciju snage. Karakteristično je da se cirkulirajuća snaga može pojaviti i kod blokiranog prenosnika kada nema relativnog kretanja elemenata unutar prenosnika. Obrtni moment koji prenose pojedini elementi prenosnika mogu višestruko premašiti vrednost ulaznog momenta koji je jednak momentu na izlazu. Da bi se utvrdio tok snage unutar prenosnika potrebno je voditi računa o odnosu momenta na elementu i ugaone brzine elementa. U opštem slučaju, ukoliko se smer vektora momenta i vektora ugaone brzine poklapa, radi se o elementu na koji ulazi snaga, i obratno, ako se smer vektora ugaone brzine i smer vektora momenta ne poklapaju radi se o elementu sa kojeg snaga izlazi. To znači da ukoliko su dva ili više članova prenosnika vezani za ulazno ili izlazno vratilo i ukoliko su spoljašnji momenti na članovima istog predznaka kao i ulazni, odnosno izlazni moment, tada dolazi do grananja ili sabiranja snage. Ukoliko je moment na nekom članu suprotnog predznaka to ima za posledicu da dolazi do pojave cirkulirajuće snage. Moguće varijante grananja snage i pojave cirkulacije snage na dva vezana elementa prenosnika prikazane su na slici 5 .

U razmatranom slučaju dvorednog prenosnika (slika 4) postoje dve varijante toka snage, u zavisnosti od vrednosti unutrašnjih prenosnih odnosa. U obe varijante dolazi do cirkulacije snage u zatvorenoj konturi između centralnih zupčanika i nosača satelita, samo u suprotnom smeru. Kad je $k_{1}>k_{2}$ aktivna snaga a)

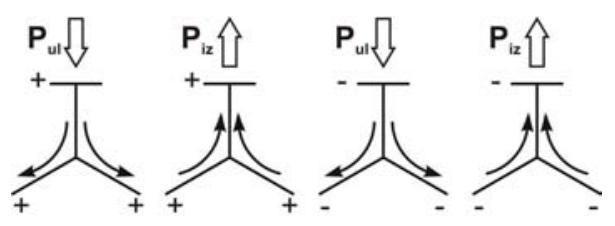

b)
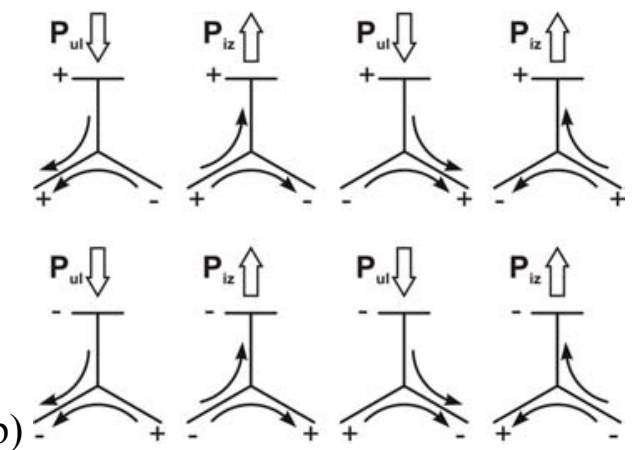

Sl. 5 - Grananje snage kod planetarnog prenosnika: a) grananje snage; b) cirkulacija snage

se prenosi tokom prikazanim na slici 4 . U slučaju jednakosti unutrašnjih prenosnih odnosa oba planetarna reda unutar prenosnika se prenosi samo cirkulirajuća snaga, a na izlazno vratilo nema prenosa snage i ono se ne obrće.

U slučaju da je prenosnik blokiran, njegov prenosni odnos jednak je jedinici, ali tok snage kroz prenosnik zavisi od načina vezivanja elemenata, odnosno načina blokiranja prenosnika. Zbog toga je veoma važno odrediti tokove aktivne $i$ cirkulirajuće snage unutar prenosnika, odnosno opterećenja pojedinih elemenata. Za određivanje tokova aktivne i cirkulirajuće snage važe ista pravila kao za određivanje toka snage kod prenosnika koji nije blokiran, uz napomenu da je, zbog jednakih ugaonih brzina elemenata, tok snage unutar prenosnika ekvivalentan toku momenta, što ima za posledicu da tok snage kroz prenosnik zavisi od pred- 
znaka momenta. Moguće varijante toka snage u ovom slučaju prikazane su na slici 6 , bez obzira na to da li se radi o aktivnoj ili cirkulirajućoj snazi. Znak + ili određuje predznak obrtnog momenta na elementu prenosnika.
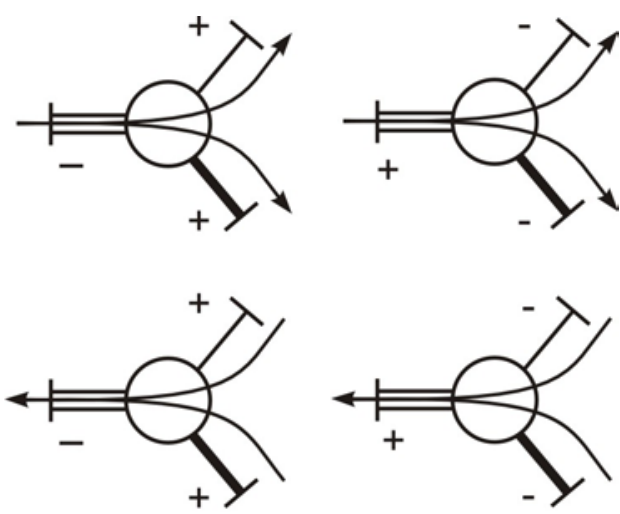

Sl. 6-Tok snage kroz blokirani planetarni red

Jedna varijanta blokiranja prenosnika sa slike 4 prikazana je na slici 7 preko kinematičke i strukturne šeme pomoću koje su tokovi snage određeni za varijantu $k_{1}<k_{2}$.

\section{Strukturna analiza prenosnika tipa Ravigneaux}

$\mathrm{U}$ analizi prenosnika Ravigneaux mogu se primeniti isti principi koji va- že za analizu složenih planetarnih prenosnika na bazi planetarnog reda sa spoljašnjim i unutrašnjim ozubljenjem. Na slici 8 prikazana je kinematička i strukturna šema jedne varijante prenosnika tipa Ravigneaux, koja može ilustrovati način njihove analize. Na šemi je prikazan postupak određivanja opterećenja elemenata prenosnika, uzimajući kao prvi element centralni zupčanik drugog planetarnog reda. Analiza se vrši pod pretpostavkom da prenosnik ima razdvojene elemente, uz izračunavanje opterećenja pojedinačnih elemenata.

Opterećenja zajedničkih elemenata izračunavaju se sumiranjem parcijalnih opterećenja. Tako se moment na zajedničkom centralnom zupčaniku, koji je istovremeno i ulazni moment, izračunava na sledeći način:

$T_{u l}=1-\frac{1+k_{2}}{1+k_{1}}=-\frac{k_{2}-k_{1}}{1+k_{1}}$

Prenosni odnos izračunava se na osnovu sledeće relacije:

$i=-\frac{T_{i z}}{T_{u l}}=\frac{k_{2}\left(1+k_{1}\right)}{k_{2}-k_{1}}$

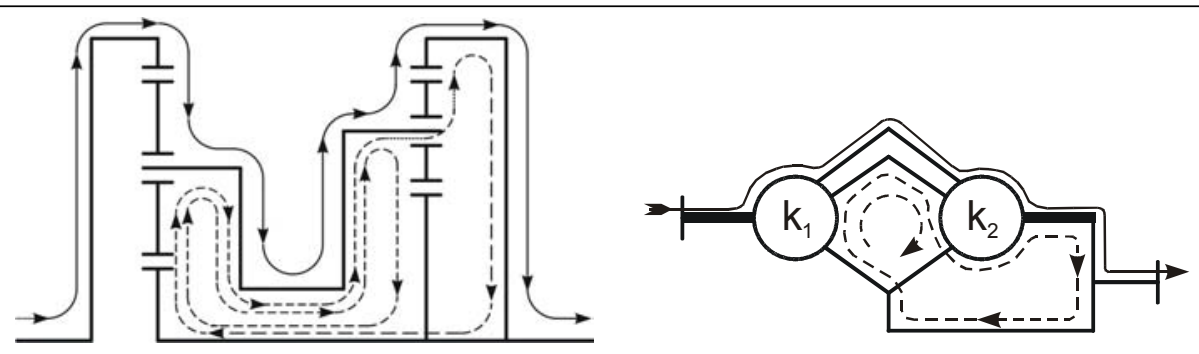

Sl. 7 - Tok snage kroz blokirani dvoredni planetarni prenosnik 


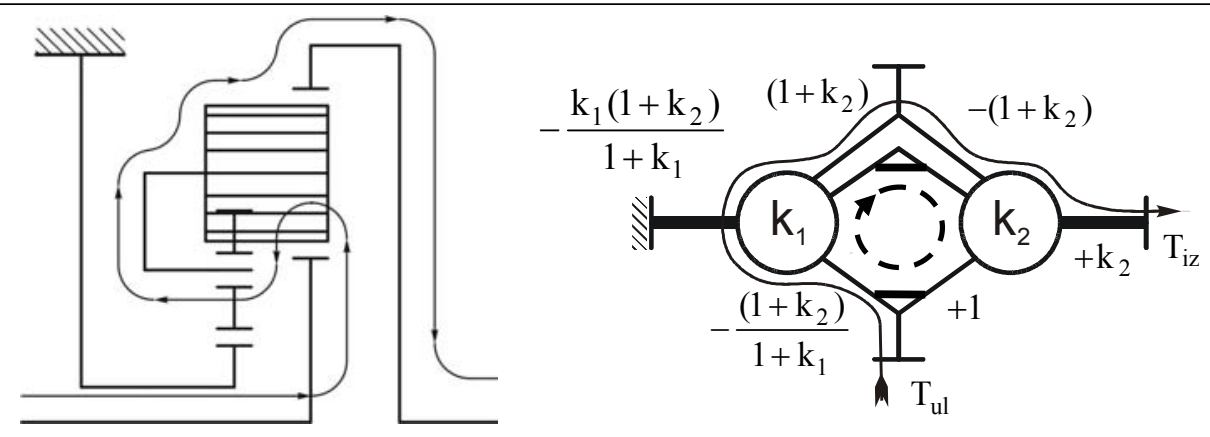

Sl. 8 - Strukturna analiza jednog funkcionalnog stanja prenosnika Ravigneaux

U slučaju jediničnog ulaznog momenta, moment na izlaznom elementu iznosi:

$$
T_{i z}=-\frac{1+k_{1}}{k_{2}-k_{1}} \cdot k_{2}=T_{u l}\left(-\frac{k_{2}\left(1+k_{1}\right)}{k_{2}-k_{1}}\right)
$$

Prenosni odnos u ovom slučaju jednak je negativnoj vrednosti izlaznog momenta, što potvrđuje tačnost izračunavanja prenosnog odnosa.

Moment na elementu koji je zakočen (u ovom slučaju centralni zupčanik b') za jedinični ulazni moment je:

$$
\begin{aligned}
T_{k} & =\left(-\frac{1+k_{1}}{k_{2}-k_{1}}\right) \cdot\left(-\frac{k_{1}\left(1+k_{2}\right)}{1+k_{1}}\right) \\
T_{k} & =T_{u l} \frac{k_{1}\left(1+k_{2}\right)}{k_{2}-k_{1}}
\end{aligned}
$$

Momenti na ulaznom, izlaznom i kočenom elementu, koji su spoljašnji za prenosnik, moraju zadovoljiti jednačinu (6), što je u ovom slučaju ispunjeno i što predstavlja potvrdu tačnosti proračuna.

Tok snage unutar prenosnika odreden je na osnovu predznaka momenata na elementima prenosnika (strukturna šema, slika 8). Prema strukturnoj šemi sna- ga se prenosi kroz dva toka, kao aktivna i cirkulirajuća. Aktivna snaga prenosi se tokom prikazanim punom linijom, dok je tok cirkulirajuce snage prikazan isprekidanom linijom. S obzirom na nepostojanje zatvorene konture koja je prikazana na šemi, zbog toga što su centralni zupčanik i nosač satelita zajednički za oba planetarna reda, ne postoji mogućnost toka cirkulirajuće snage, tako da se ovaj tok kod prenosnika Ravigneaux ne prikazuje. Na kinematičkoj šemi (slika 8) prikazan je samo tok aktivne snage koja se prenosi kroz elemente prenosnika.

Blokiranjem prenosnika ostvaruje se vrednost prenosnog odnosa jednaka jedinici, ali opterećenja elemenata i tok snage zavise od načina blokiranja. Uticaj načina blokiranja prenosnika Ravigneaux na tokove snage ilustrovan je na slici 9 . Ukoliko se blokiranje obezbedi vezivanjem centralnih zupčanika sa spoljašnjim ozubljenjem (slika 9a) snaga se deli unutar prenosnika, što znači da su elementi unutar prenosnika opterećeni manjim momentom od momenta koji se prenosi. Kod blokiranja prenosnika, kao na slici $9 b$ ), dolazi do pojave cirkulacije snage i dodatnog opterećenja centralnog zupčanika sa unutrašnjim ozubljenjem koji 


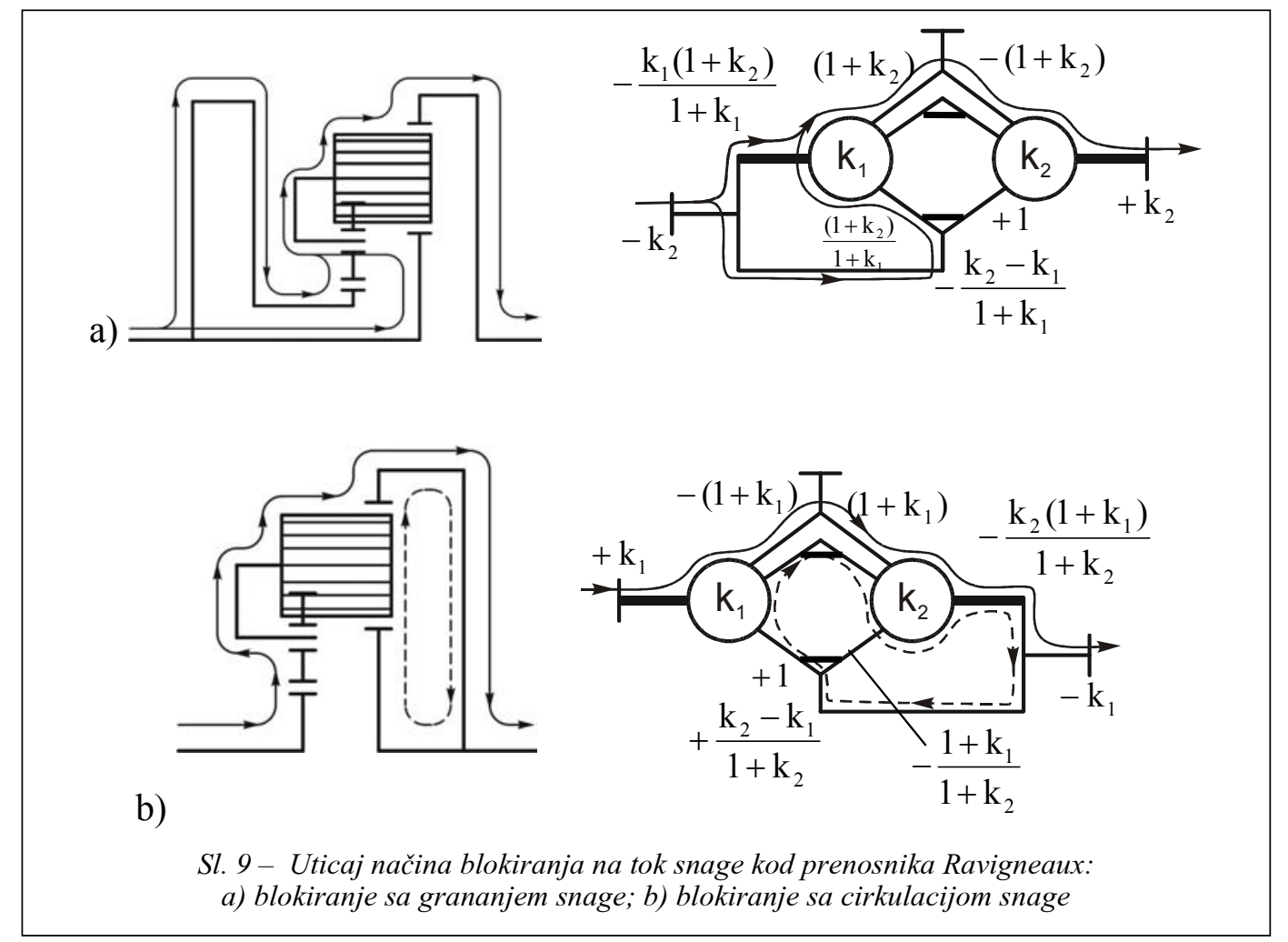

prenosi aktivni i cirkulirajući moment koji je veći od ulaznog momenta. Ovu činjenicu treba imati u vidu pri izboru načina blokiranja prenosnika, ako je to moguće, pošto prikazane strukture nisu jedini načini blokiranja prenosnika.

\section{Strukturna analiza složenih prenosnika}

Primena strukturne šeme posebno je korisna za analizu složenih kinematičkih šema koje se često pojavljuju kod menjačkih prenosnika motornih vozila. Za konkretne vrednosti unutrašnjih prenosnih odnosa prikazaće se kinematičke i strukturne šeme nekih funkcionalnih stanja karakterističnih rešenja planetarnih menjačkih prenosnika brzohodnih guseničnih vozila.
Na slici 10 prikazana je struktura trorednog prenosnika koja se pojavljuje u trećem stepenu prenosa menjačkog prenosnika tenka T-72 [11]. Unutrašnji prenosni odnosi navedenog prenosnika su sledeći: $k_{1}=2,11 ; k_{2}=4,57$ i $k_{3}=2,08$. Prenosni odnos, opterećenja elemenata i tok snage prikazani su na struktunoj šemi. Tok snage u zatvorenoj konturi, koju čine elementi prva dva planetarna reda, lako se određuje na osnovu predznaka opterećeja. Da bi se odredio tok snage u ostalom delu strukture potrebno je, pored predznaka opterećenja elemenata prenosnika, poznavati i predznak ugaone brzine, što se može relativno lako dobiti analizom kinematike prenosnika kojom je utvrđeno da ugaone brzine svih elemenata imaju isti predznak. Na taj način jednoznačno se određuje da snaga ulazi na 


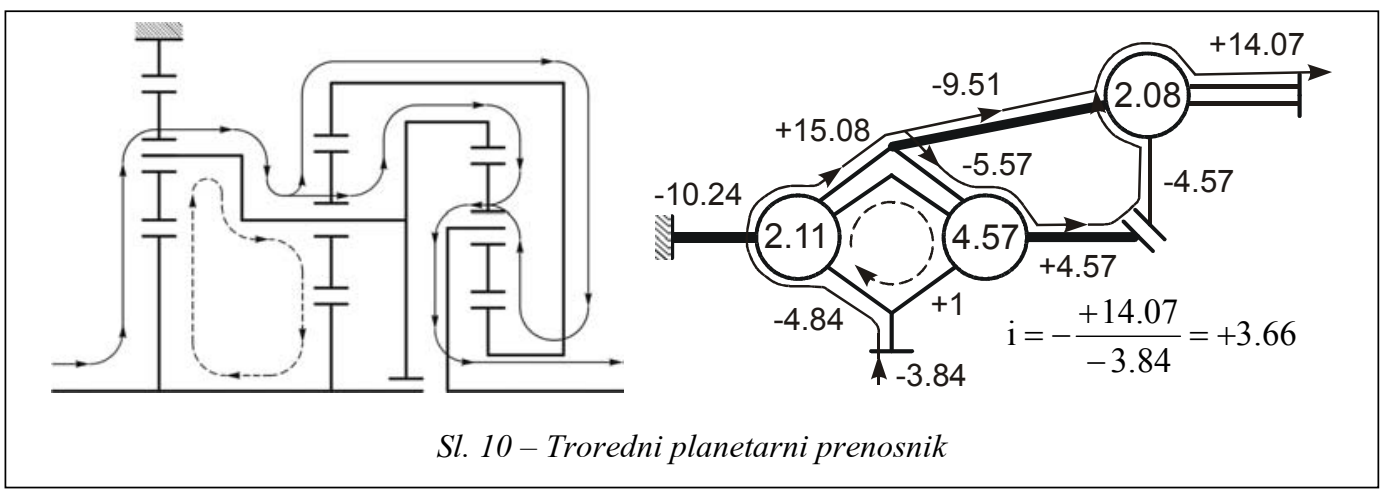

oba elementa trećeg planetarnog reda, čime su potpuno definisani tokovi snage.

$\mathrm{Na}$ slici 11 prikazana je struktura paralelne veze prenosnika tipa Ravigneaux i jednorednog prenosnika, koja se pojavljuje u drugom stepenu prenosa menjačkog prenosnika tenka T-80 [12]. Unutrašnji prenosni odnosi su: $k_{1}=0,86$; $k_{2}=2,0 ; k_{3}=2,18$. Strukturna šema ovog prenosnika istovetna je strukturnoj šemi prenosnika prikazanog na slici 10 , tako da se i analiza obavlja na isti način. Jedina razlika je što se kod prenosnika Ravigneaux ne pojavljuje cirkulirajuća snaga. Moment na nosaču satelita prenosnika Ravigneaux jednak je sumi parcijalnih momenata i iznosi -4,18, slika 11 (negativna vrednost momenta centralnog zupčanika sa unutrašnjim ozubljenjem trećeg planetarnog reda). Moment na ulaznom elementu takođe je jednak sumi parcijalnih momenata i iznosi $+2,55$. Vrednost prethodna dva momenta izražena je u odnosu na moment centralnog zupčanika trećeg planetarnog reda koji je usvojen kao jedinični.

$\mathrm{Na}$ slici 12 prikazana je struktura četverorednog blokiranog prenosnika koja se pojavljuje u sedmom stepenu prenosa menjačkog prenosnika tenka T-72.

Vrednosti momenata koje su prikazane na strukturnoj šemi svedene su na jedinični ulazni moment radi sagledavanja maksimalnih opterećenja pojedinih elemenata. $\mathrm{Na}$ osnovu predznaka momenta određen je tok snage, gde se pokazuje da unutar prenosnika postoji grananje snage, kao i dve zatvorene konture koje izazivaju pojavu cirkulirajuće snage. Kao posledica ovakvog načina prenosa
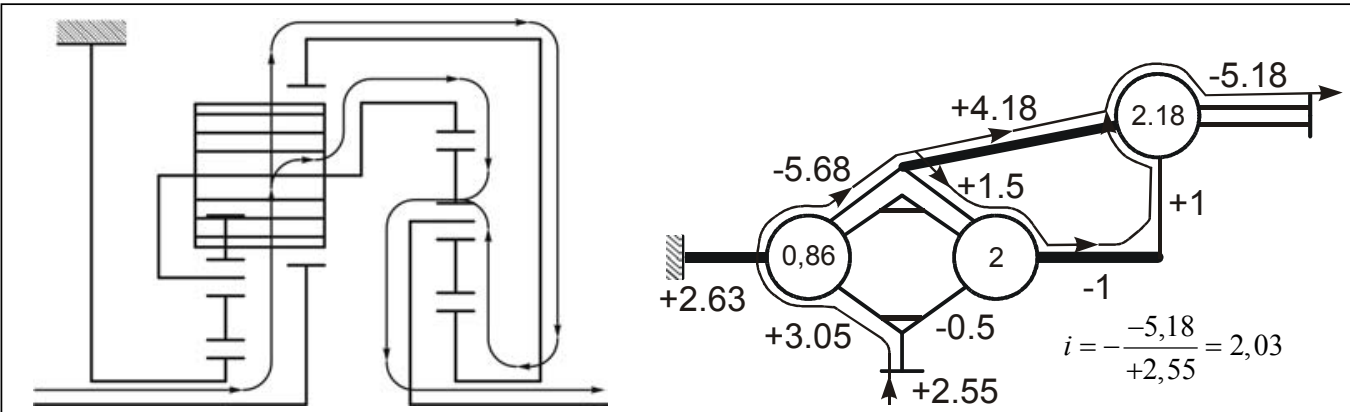

Sl. 11 - Paralelna veza prenosnika Ravigneaux i jednorednog prenosnika 


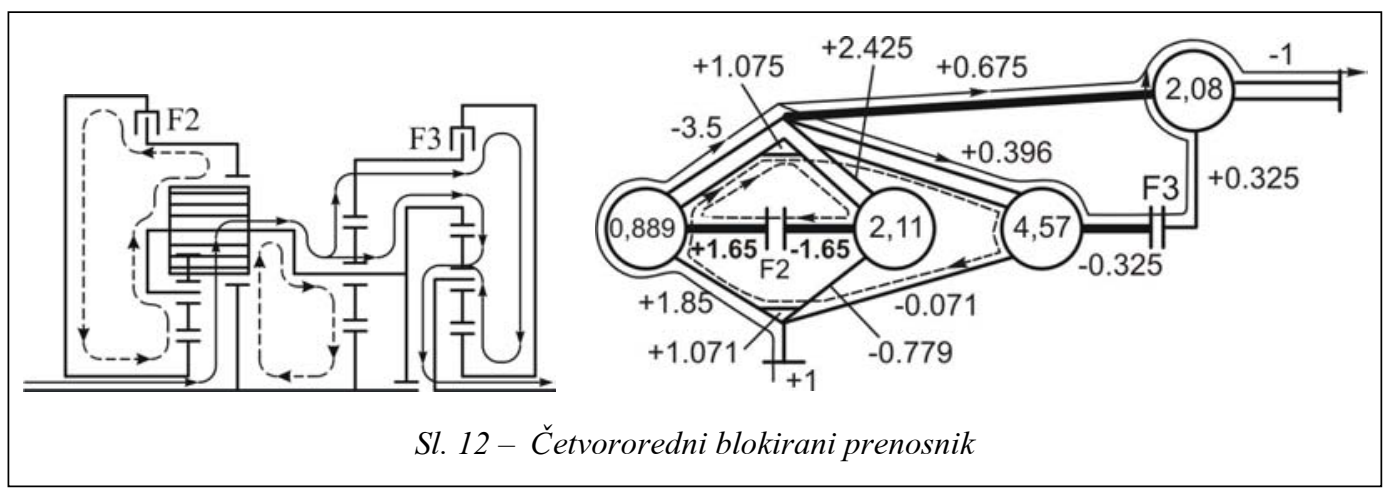

snage moment kojim je opterećena spojnica koja spaja centralni zupčanik sa spoljašnjim ozubljenjem prvog planetarnog reda i centralni zupčanik sa unutrašnjim ozubljenjem drugog planetarnog reda (F2) veći je za 1,645 puta od ulaznog momenta. Ovaj moment ujedno je i maksimalni moment koji prenosnik prenosi $\mathrm{u}$ ovom funkcionalnom stanju, jer je moment na nosaču satelita prenosnika Ravigneaux jednak sumi parcijalnih momenata $\left((-3,5+2,425) T_{u l}=1,075 T_{u l}\right)$.

\section{Zaključak}

Predstavljanje složenog planetarnog prenosnika pomoću strukturnog simbola omogućava bolje sagledavanje međusobnih veza elemenata prenosnika $i$ analizu njegovih kinematičkih i dinamičkih karakteristika. Uopštena polužna analogija i primena strukturnog simbola za analizu karakteristika planetarnog reda sa spoljašnjim ozubljenjem, na način kako je to prezentovano u ovom radu, omogućava strukturnu analizu prenosnika tipa Ravigneaux i složenih prenosnika koji u svojoj strukturi imaju navedeni prenosnik, čime se pojednostavljuje analiza navedenih prenosnika. Metod strukturne analize po- sebno je koristan pri analizi složenih višerednih prenosnika, bilo da se radi o blokiranom prenosniku ili prenosniku sa jednim stepenom slobode.

\section{Literatura:}

[1] Pantić, M.: Gubici snage u ozubljenju kao parametar za formiranje optimalne kinematske šeme planetarnih prenosnika primenjenih u sistemu za prenos snage motornih vozila, doktorska disertacija, Mašinski fakultet, Beograd, 1997.

[2] Muždeka, S.; Arsenić, Ž.: Virtual models of planetary transmissions, International Journal for Vehicle Mechanics, Engines and Transpotration systems (Mobility \& Vehicles Mechanics), Volume 29, Number 1, Kragujevac, march 2003, pp. 33-42.

[3] Pantić, M.; Muždeka, S.: Neki problemi projektovanja složenih planetarnih prenosnika snage, Naučno-stručni skup IRMES 2004, Kragujevac, 2004.

[4] Arnaudov, K.: Eingaches Verfahren zur Ermittlung des Ubersetzungsverhaltnisses zusammengesetzter Planetengetriebe, VDI-Berichte 1230 (Internationale Conference on Gears, Dresden 1996), VDI-Verlag GmbH, Dusseldorf, 1996, s. 313-327.

[5] Arnaudov, K.; Karaivanov, D.: Engineering analysis of the coupled two-carier planetary gearing through the lever analogy, International Conference on Mechanical Transmissions, Chongquing, China, 2001.

[6] Arnaudov, K.; Karaivanov, D.: Coupled multi caraier planetary gears, their systematics, properties and abilities, International conference „Power Transmissions 03“, Varna 2003.

[7] Wolf, A.: Die Grundlagen der Umlaufgetriebe, Braunschweig: Freider, Vieweg\&Sohn, 1958.

[8] Muler, H., W.: Die Umlaufgetriebe, Berlin Springer Verlag, 1996.

[9] Looman, J.: Zahnradgetriebe, Berlin, Springer Verlag, 1996.

[10] Stojković, V.: Doprinos sintezi planetarnih prijenosnika sa tri stupnja slobode radi primjene na brzohodnim oklopnim gusjeničnim vozilima, disertacija, VVTŠ KoV JNA, Zagreb, 1989.

[11] Tenk T-72, TU-I, SSNO, Beograd.

[12] Popov, N., S.: Transportnie mašini s gazoturbinnimi dvigateljami, Mašinostroenie, Moskva, 1987. 


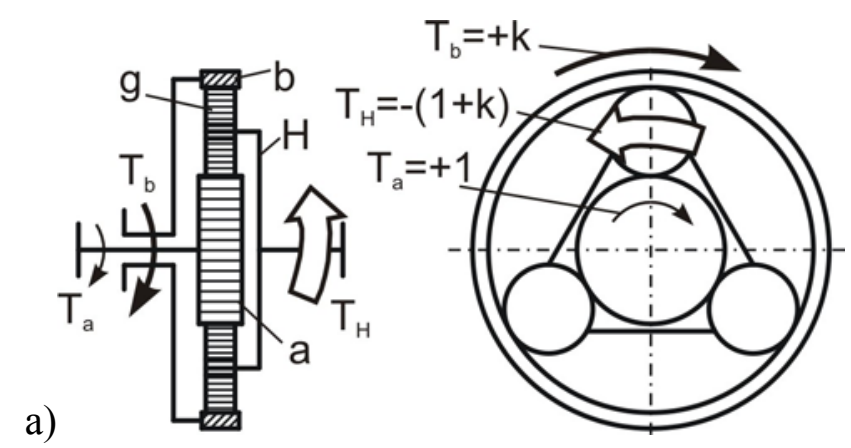

b)

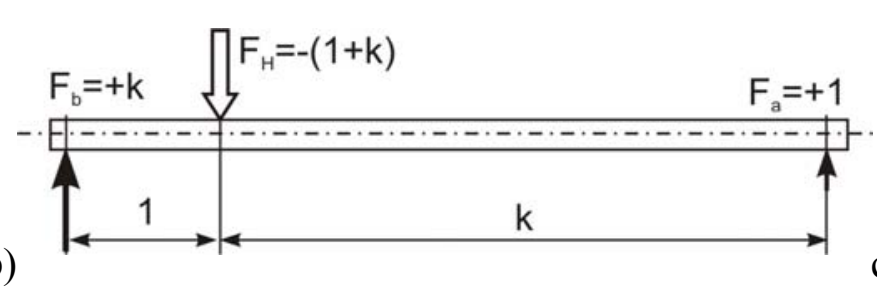

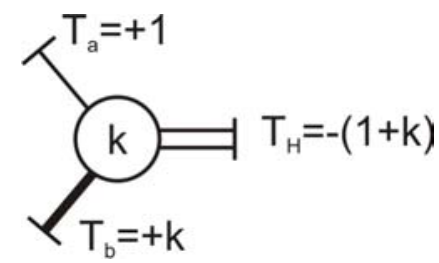

c)

Sl. 1 - Planetarni red sa spoljašnjim i unutrašnjim ozubljenjem: a) kinematička šema; b) polužna analogija; c) strukturni (Wolfov) simbol
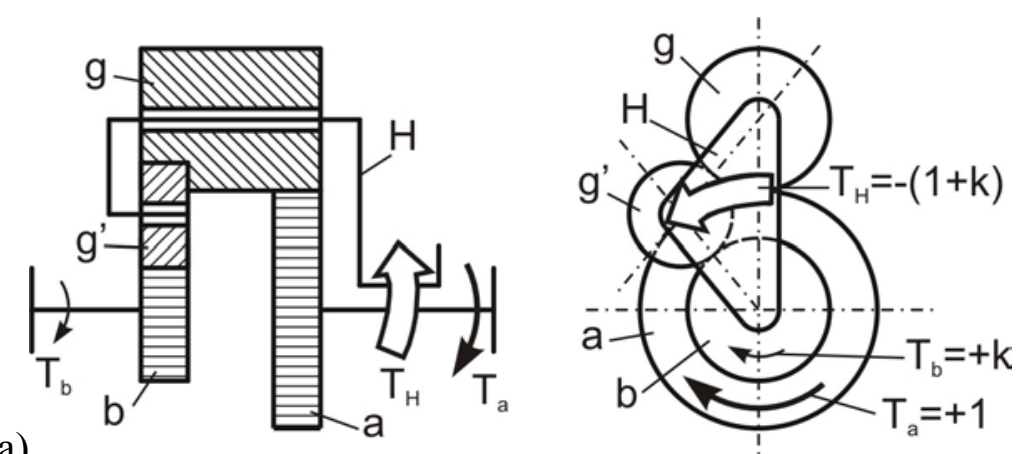

a)

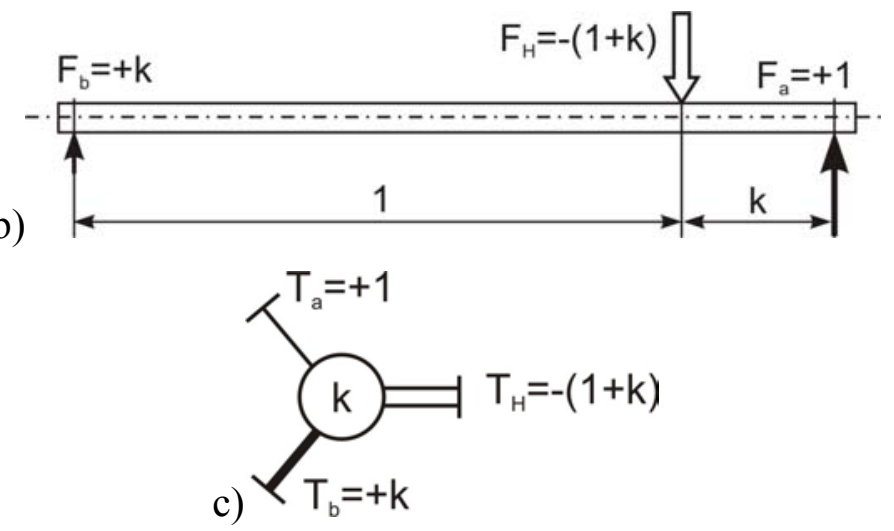




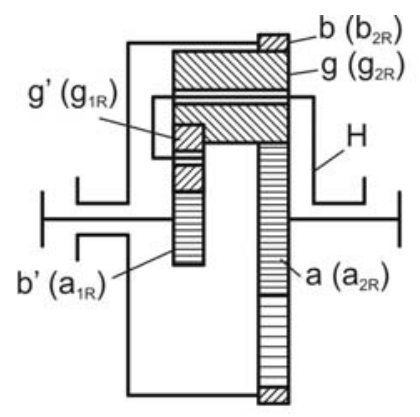

a)

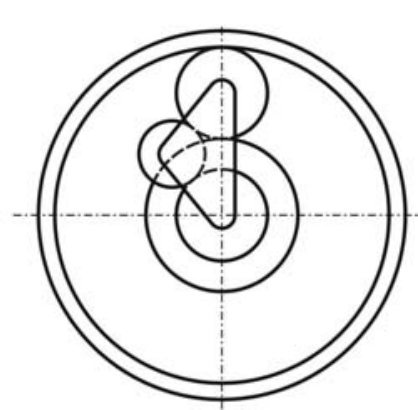

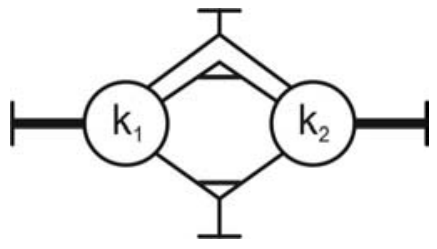

b)

Sl. 3 - Prenosnik tipa Ravigneaux: a) Kinematička šema; b) Strukturni simbol
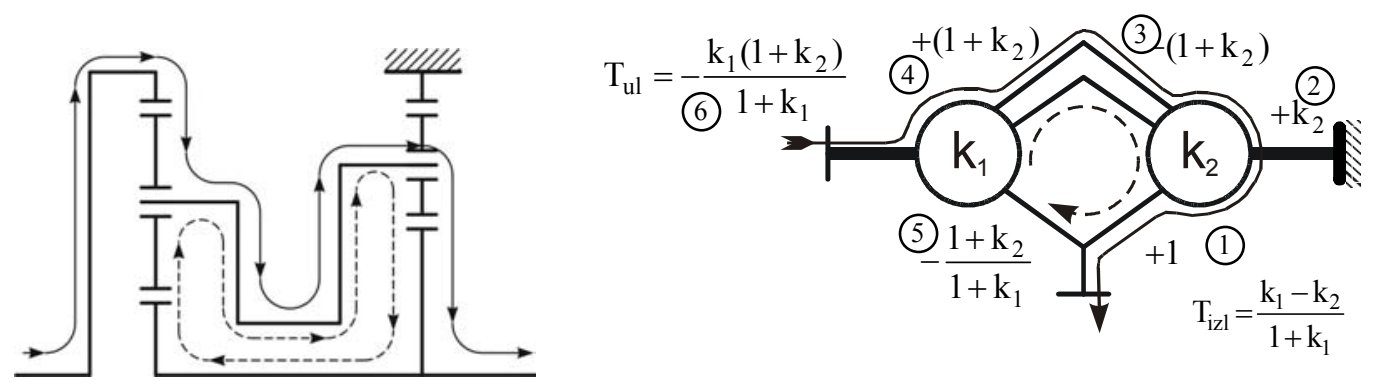

Sl. 4 - Dvoredni planetarni prenosnik 
a)

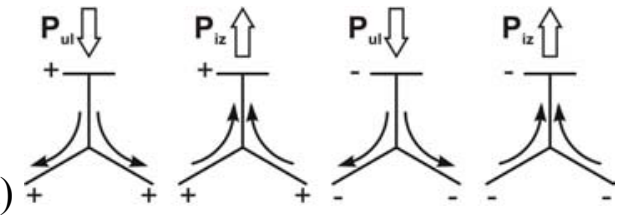

b)
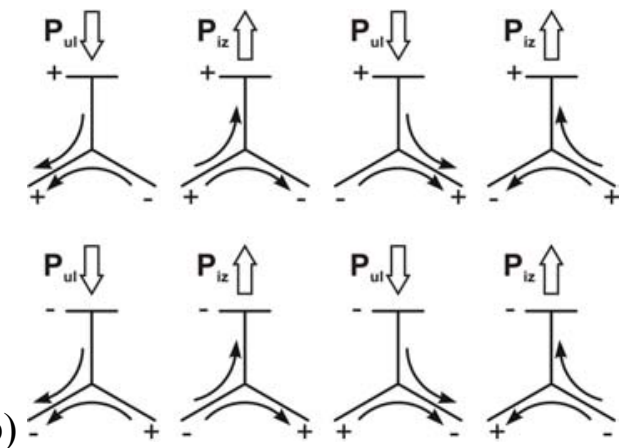

Sl. 5 - Grananje snage kod planetarnog prenosnika: a) grananje snage; b) cirkulacija snage
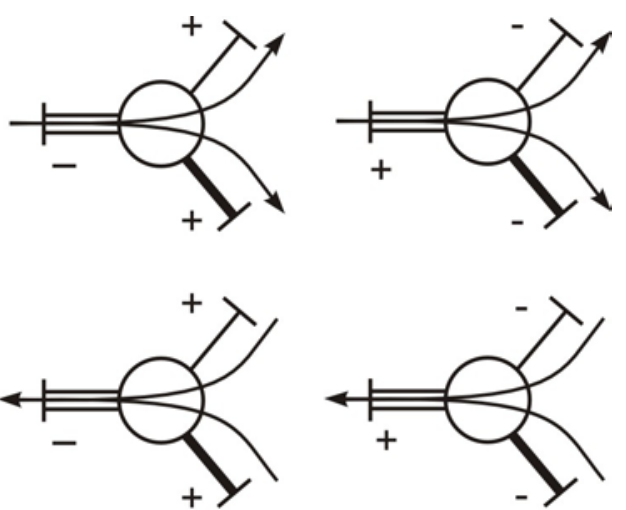

Sl. 6-Tok snage kroz blokirani planetarni red 


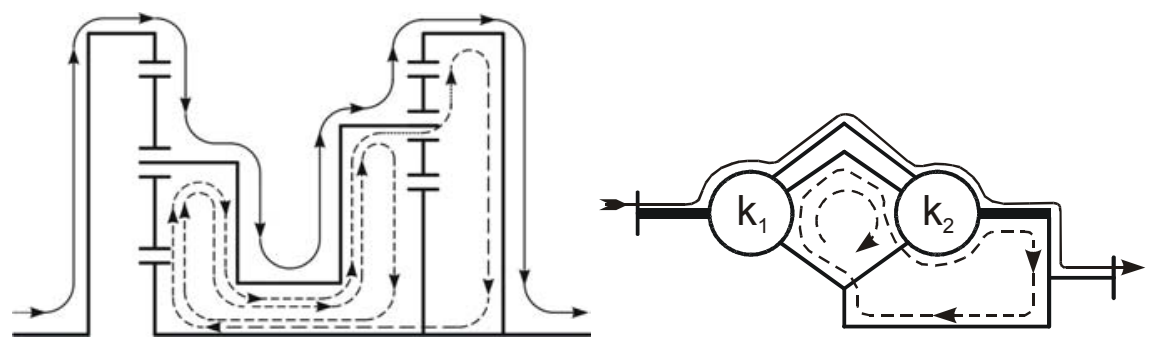

Sl. 7 - Tok snage kroz blokirani dvoredni planetarni prenosnik $\underset{1=}{=} \frac{-5,18}{+2,55}=2,03$
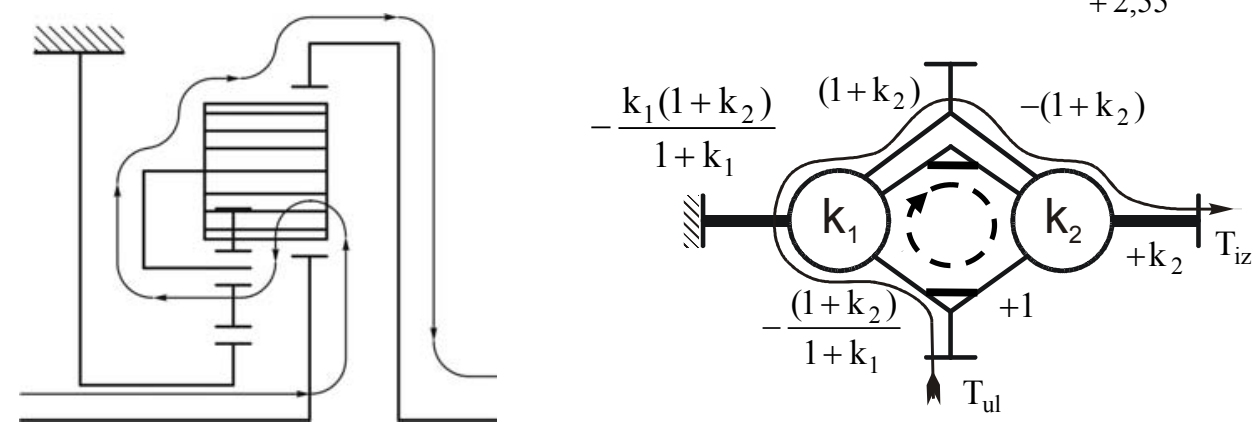

Sl 8 - Strukturna analiza jednog funkcionalnog stanja prenosnika Ravigneaux

a)
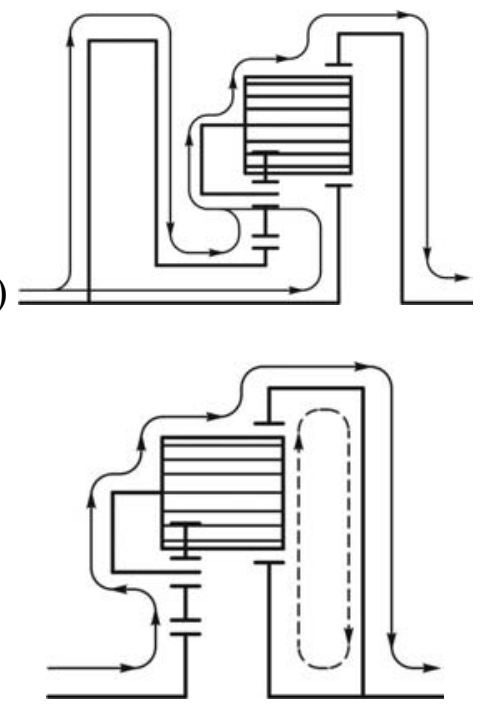

b)

Sl. 9 - Uticaj načina blokiranja na tok snage kod prenosnika Ravigneaux: a) blokiranje sa grananjem snage; b) blokiranje sa cirkulacijom snage 

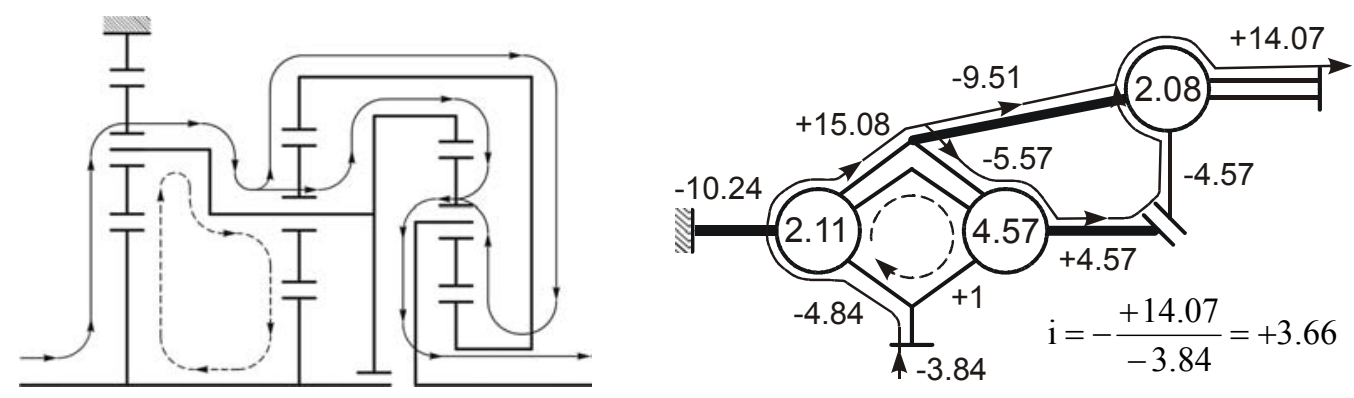

Sl 10 - Troredni planetarni prenosnik
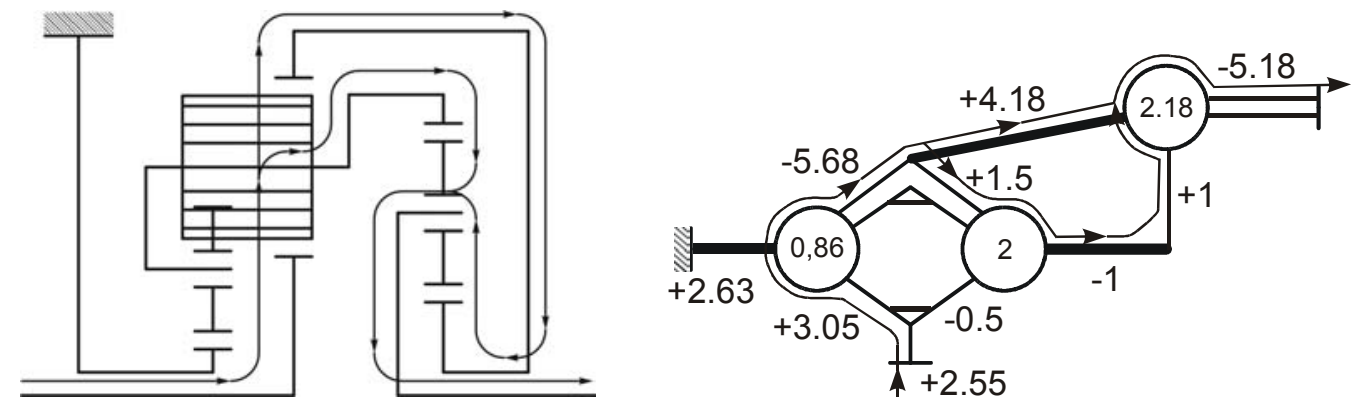

Sl 11 - Paralelna veza prenosnika Ravigneaux i jednorednog prenosnika
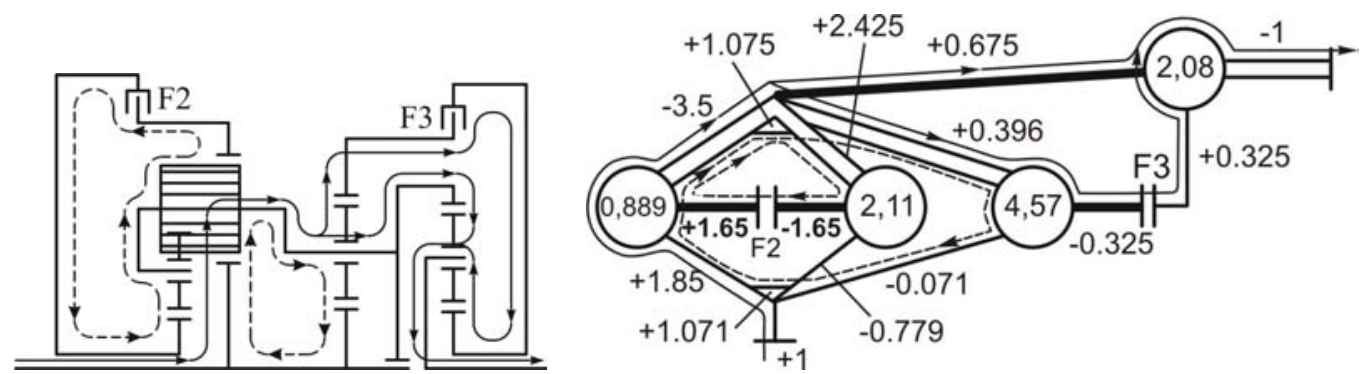

Sl. 12 - Četvororedni blokirani prenosnik 